\title{
The Stock Price Performance and Return Style of the Pan-Infrastructure Reits Corporation: Evidence from U.S. and Japan Market
}

\author{
Wei-Shen $\mathrm{Li}^{1,2}$ \\ ${ }^{1}$ School of Busniess, Nanjing University, Nanjing, China \\ ${ }^{2}$ Alan AMC, Beijing, China \\ Correspondence: Wei-Shen Li, Beijing Alan AMC, 3rd in Xinjiekou North Street, Xicheng District, Beijing, \\ China. Tel: 86-177-0135-4768.
}

Received: January 14, 2021

Accepted: February 18, 2022

Online Published: February 22, 2022

doi:10.5539/ijef.v14n3p100

URL: https://doi.org/10.5539/ijef.v14n3p100

\begin{abstract}
The growth of big data analytics, cloud computing and 5G communication promotes the expansion of Pan-infrastructure REITs market. Despite previous studies confirmed the value-added role of pan-infrastructure REITs in a mixed-asset portfolio at the framework of mean-variance optimization, the anti-recession characteristics and stock-bond mixed feature of pan-infrastructure REITs is still scarcely investigated until now. In this paper, targeting at the U.S. and Japanese pan-infrastructure REITs market, we employ the capital asset price model (CAPM) and Sharpe model to conduct an empirical research to clarify the aforementioned issue, and the corresponding results indicate that in U.S. REITs market, the return style of new-infrastructure REITs corporation whose underlying asset covering data center, communication tower reveals the substantial anti-volatility characteristics under the increasing macroeconomic uncertainty, while the industrial REITs and infrastructure REITs corporation which belongs to the public utility sub-sector has revealed the completely opposite trend that the stock constituents account for a higher percentage of its return style, simultaneously. On the other hand, the results from horizontal comparison also suggest that the pan-infrastructure REITs corporation in Japan has more remarkable defensive characteristics with higher ratio of bond constituents than that in U.S. Such results uncover the impact of sectoral effect and market distinction on the stock price performance and return style of relevant pan-infrastructure REITs corporation in various countries and are also beneficial to the risk control activity of institutional investors.
\end{abstract}

Keywords: Pan-infrastructure REITs, Jensen Alpha, CAPM Model, Sharpe Model

\section{Introduction}

The pan-infrastructure, which covers a wider range of assets not only including traditional industrial facilities, but also encompassing some new types of property sectors such as logistics properties, data centers, communication towers, self-storages, energy transmission facilities, highway, railroad and wastewater treatment facilities, its current situation of corresponding real estate investment and trust (REITs) market varies considerably from one country to another (China securities regulatory commission, 2020; NAREIT, 2016; J-REIT.jp, 2020).

Table 1(a) illustrates the comparison between the pan-infrastructure REITs market in U.S. and Japan in light of their coverage, asset types, trading sections and history. The results display that the definition and coverage of pan-infrastructure REITs market in two countries exists substantial difference. On one hand, the coverage of pan-infrastructure REITs market in Japan is very narrow that only including industrial \& logistics and infrastructure sectors, and the further classification of every asset sector is also ambiguous. Meanwhile, only 17 pan-infrastructure REITs corporations most of which have a shorter history are listed on the Tokyo stock exchange (TSE). Additionally, TSE also established the REITs and infrastructure fund section separately and treated them as two mutual independent markets in terms of the trading series (Tokyo Stock Exchange, 2020).

In contrast, the classification of pan-infrastructure REITs corporation in U.S whose underlying assets cover four kinds of sectors such as industrial \& logistics facilities, self-storage, infrastructure and data center is more explicit than that in Japan. Accordingly, the pan-infrastructure REITs market is more mature with a longer 
history and larger number of listed corporations. Besides, all of pan-infrastructure REITs corporations are listed on New York stock exchange or Nasdaq and do not belong to any independent trading sections (NAREIT, 2016).

In addition, we also notice that the U.S. infrastructure REITs market can be divided into at least three sub-sectors covering the communication tower, energy pipeline facilities and communication distribution system. Table 1(b) display their respective market scale and share, and three large sized communication tower focused REITs corporations whose total market capitalization amounts to 200 billion dollars dominate the market that accounting for 98 percent of market share; whilst only 2 percent market share belongs to other sub-sector infrastructure REITs corporations. Such market structure also promotes us not to neglect the sub-sector specific characteristics when assessing the performance of six U.S. infrastructure REITs corporations.

Table 1(a). The coverage of pan-infrastructure REITs market in U.S. and Japan

\begin{tabular}{|c|c|c|c|c|c|}
\hline Market & Sector & $\begin{array}{l}\text { Listed } \\
\text { number }\end{array}$ & $\begin{array}{c}\text { Further classification of } \\
\text { underlying assets }\end{array}$ & Trading section & Establishing Year \\
\hline \multirow{3}{*}{ Japan } & $\begin{array}{l}\text { Logistics } \\
\text { REITs }\end{array}$ & 10 & $\begin{array}{l}\text { Mainly focus on logistics facilities } \\
\text { and traditional industrial facilities, } \\
\text { supplemented by new } \\
\text { infrastructure covering data center }\end{array}$ & TSE REITs section & 2005 \\
\hline & $\begin{array}{l}\text { Infrastructure } \\
\text { fund }\end{array}$ & 7 & Solar energy power station & $\begin{array}{l}\text { TSE infrastructure fund } \\
\text { section which is independent } \\
\text { of the TSE REITs section }\end{array}$ & 2015 \\
\hline & $\begin{array}{l}\text { Data center } \\
\text { REITs }\end{array}$ & 5 & Data Center & $\begin{array}{l}\text { Listed on New York Stock } \\
\text { Exchange or Nasdaq }\end{array}$ & 2004 \\
\hline \multirow[t]{3}{*}{ U.S. } & $\begin{array}{l}\text { Infrastructure } \\
\text { REITs }\end{array}$ & 6 & $\begin{array}{l}\text { Telecommunication tower, energy } \\
\text { pipeline facilities and } \\
\text { communication distribution } \\
\text { systems }\end{array}$ & $\begin{array}{l}\text { Listed on New York Stock } \\
\text { Exchange or Nasdaq }\end{array}$ & $\begin{array}{l}\text { 1999, 2007, } 2015 \text { for } \\
\text { communication tower, } \\
\text { energy facilities, } \\
\text { communication } \\
\text { distribution system, } \\
\text { respectively }\end{array}$ \\
\hline & $\begin{array}{l}\text { Self-Storage } \\
\text { REITs }\end{array}$ & 6 & Self-Storage & $\begin{array}{l}\text { Listed on New York Stock } \\
\text { Exchange or Nasdaq }\end{array}$ & 1986 \\
\hline & $\begin{array}{l}\text { Industrial and } \\
\text { logistics REITs }\end{array}$ & 13 & $\begin{array}{l}\text { Industrial facilities, distribution } \\
\text { center and warehouse }\end{array}$ & $\begin{array}{l}\text { Listed on New York Stock } \\
\text { Exchange or Nasdaq }\end{array}$ & 1971 \\
\hline
\end{tabular}

Table 1(b). The market scale and share of U.S. infrastructure REITs corporations belonging to various sub-sectors in FY 2020

\begin{tabular}{|c|c|c|c|}
\hline Sub-Sector & Corporations & Market Cap (Billion Dollars) & Market Share \\
\hline \multirow{3}{*}{ Communication Towers } & AMT & 99.5 & $49.08 \%$ \\
\hline & CCI & 68.66 & $33.87 \%$ \\
\hline & SBAC & 31.49 & $15.53 \%$ \\
\hline Communication Distribution System & UNITI & 2.73 & $1.35 \%$ \\
\hline Energy Pipeline Facilities & CORR & 0.09 & $0.04 \%$ \\
\hline $\begin{array}{l}\text { Renewable Power generation and site for wireless } \\
\text { communication equipment }\end{array}$ & LMRK & 0.27 & $0.13 \%$ \\
\hline- & Total & 202.74 & $100.00 \%$ \\
\hline
\end{tabular}

In recent years, the revolution of science and technology has contributed to the continuous establishment of new types of infrastructure covering logistics facilities, data center, self-storage, communication tower and so on. For one thing, the growth of e-commerce promotes the evolution of omnichannel retail platforms and enhances the demand of logistics facilities (Bohjalian, 2018; CBRE, 2018; Knight Frank, 2018; World Bank, 2018; Chong, 2019; Xu et al., 2019; Lin et al., 2020); for another thing, the breakthrough of high tech-digital technologies including big data analytics, artificial intelligence (AI), internet of things (IOT), cloud computing and 5G telecommunications brings about the prosperity of data centers and communication towers (Newell \& Peng, 2008; Oyedele, 2014; McIntosh et al., 2017; Marzuki \& Newell, 2019). 
Accordingly, the scale of corresponding pan-infrastructure REITs market has raised dramatically during last decade as shown in Table 2. In U.S., the pan-infrastructure REITs corporations constitute $44.76 \%$ of the total REITs market capitalization in 2020, which has achieved the reshuffle of market pattern that the traditional commercial properties such as office building, retailing center accounting for most of market share in the REITs market in 2009 (NAREIT, 2009; NAREIT, 2020). Meanwhile, the growth of pan-infrastructure REITs market is also evident in Japan during post-global financial crisis period, and the market capitalization of the logistics REITs and infrastructure fund corporation has increased from 1.11 billion dollars in 2009 to 32.51 billion dollars in 2020, which eventually becomes a significant component in J-REITs market (ARES, 2009; ARES, 2020).

Table 2. The market share of pan-infrastructure REITs corporation in U.S. and Japan

\begin{tabular}{|c|c|c|c|c|c|}
\hline Country & Year & $\begin{array}{c}\text { Market Capitalization of composite } \\
\text { REITs market (Billion Dollars) }\end{array}$ & Sector & $\begin{array}{l}\text { Market Capitalization } \\
\text { (Billion Dollars) }\end{array}$ & $\begin{array}{c}\text { The ratio of pan-infrastructure } \\
\text { REITs market }\end{array}$ \\
\hline \multirow{7}{*}{ U.S. } & \multirow{3}{*}{2009} & \multirow{3}{*}{247.71} & Industrial & 13.15 & \multirow{3}{*}{$15.12 \%$} \\
\hline & & & Self-Storage & 16.52 & \\
\hline & & & Other pan-infrastructure & 7.79 & \\
\hline & \multirow{4}{*}{2020} & \multirow{4}{*}{1182.95} & Industrial & 135.76 & \multirow{4}{*}{$44.76 \%$} \\
\hline & & & Self-Storage & 70.15 & \\
\hline & & & Data Center & 120.84 & \\
\hline & & & Infrastructure & 202.74 & \\
\hline \multirow{3}{*}{ Japan } & 2009 & 29.43 & Logistics & 1.11 & $3.77 \%$ \\
\hline & \multirow{2}{*}{2020} & \multirow{2}{*}{140.72} & Logistics & 31.25 & \multirow{2}{*}{$23.10 \%$} \\
\hline & & & Infrastructure & 1.26 & \\
\hline
\end{tabular}

Table 3(a). The vulnerability of U.S. REITs corporation with various sectors to the two stock market crashes resulting from 2015-2016 selling off crisis and the breakout of COVID-19. In this context, we calculate the stock price variation of target corporations or indices between May 2015 and June 2016 to observe the influence of selling-off crisis. Meanwhile, the counterparts between January 2020 and March 2020 are obtained to evaluate the performance of target corporations/indices during 2020 stock market crash

\begin{tabular}{|c|c|c|c|c|}
\hline \multicolumn{5}{|c|}{ The vulnerability of U.S. Pan-infrastructure REITs corporation to the stock market crash } \\
\hline Country & Sector & Representative index/corporations & 2015-2016 Selling off crisis & 2020 stock market crash \\
\hline \multirow{13}{*}{ U.S. } & Industrial & FTSE NAREIT Industrial & $29.67 \%$ & $-14.21 \%$ \\
\hline & Self-storage & FTSE NAREIT Self Storage & $30.70 \%$ & $-12.70 \%$ \\
\hline & \multirow{5}{*}{ Data Center } & Equinix & $50.06 \%$ & $5.91 \%$ \\
\hline & & DLR & $65.04 \%$ & $12.94 \%$ \\
\hline & & COR & $87.90 \%$ & $-1.32 \%$ \\
\hline & & QTS & $50.36 \%$ & $1.99 \%$ \\
\hline & & Cyousone & $72.48 \%$ & $1.48 \%$ \\
\hline & \multirow{6}{*}{ Infrastructure } & AMT & $22.44 \%$ & $-6.04 \%$ \\
\hline & & $\mathrm{CCI}$ & $24.38 \%$ & $-3.63 \%$ \\
\hline & & SBAC & $-3.46 \%$ & $8.18 \%$ \\
\hline & & UNITI & $10.94 \%$ & $-4.74 \%$ \\
\hline & & LMRK & $-1.14 \%$ & $-39.48 \%$ \\
\hline & & CORR & $-13.23 \%$ & $-59.69 \%$ \\
\hline \multicolumn{5}{|c|}{ The vulnerability of other REITs sector to the stock market crash } \\
\hline \multirow{10}{*}{ U.S. } & Office Building & FTSE NAREIT Office & $6.49 \%$ & $-29.10 \%$ \\
\hline & Retail & FTSE NAREIT Retail & $18.51 \%$ & $-47.63 \%$ \\
\hline & Residence & FTSE NAREIT Residential & $14.05 \%$ & $-27.70 \%$ \\
\hline & Lodging/Resorts & FTSE NAREIT Lodging/Resorts & $-19.30 \%$ & $-46.31 \%$ \\
\hline & Diversified & FTSE NAREIT Diversified & $1.56 \%$ & $-40.89 \%$ \\
\hline & Timberland & Weyerhaeuser & $-8.57 \%$ & $-41.45 \%$ \\
\hline & Healthcare & FTSE NAREIT Healthcare & $8.20 \%$ & $-39.44 \%$ \\
\hline & Specialty & Dow Jones Specialty REITs & $18.63 \%$ & $-15.47 \%$ \\
\hline & REITs market & FTSE NAREIT All Equity REITs & $13.50 \%$ & $-25.04 \%$ \\
\hline & Benchmark & SP500 & $-0.40 \%$ & $-19.87 \%$ \\
\hline
\end{tabular}


Table 3(b). The vulnerability of Japan REITs corporations with various sectors to the two stock market crashes between 2015 and 2020. The relevant calculation process is identical to the counterparts in U.S market as indicated in Table 3(a)

\begin{tabular}{|c|c|c|c|c|}
\hline \multicolumn{5}{|c|}{ The vulnerability of Japan Pan-infrastructure REITs corporation to the stock market crash } \\
\hline Country & Sector & Representative index/corporations & 2015-2016 Selling off crisis & 2020 stock market crash \\
\hline \multirow{8}{*}{ Japan } & \multirow{4}{*}{ Logistics } & Japan Logistics Fund & $-6.18 \%$ & $-18.23 \%$ \\
\hline & & Industrial Investment Fund & $-1.38 \%$ & $-12.35 \%$ \\
\hline & & GLP Investment Corporation & $6.48 \%$ & $-16.31 \%$ \\
\hline & & Nippon Prologis REIT & $4.80 \%$ & $-13.08 \%$ \\
\hline & \multirow{4}{*}{ Infrastructure } & Takara Leben Infrastructure Fund & - & $-9.72 \%$ \\
\hline & & Ichigo Green Infrastructure Fund & - & $-8.95 \%$ \\
\hline & & Renewable Japan Energy Infrastructure Fund & - & $-12.08 \%$ \\
\hline & & Canadian Solar Infrastructure Fund & - & $-9.39 \%$ \\
\hline \multicolumn{5}{|c|}{ The vulnerability of other REITs sector to the stock market crash } \\
\hline \multirow{7}{*}{ Japan } & Office building & TSE Office REIT Index & $0.34 \%$ & $-29.63 \%$ \\
\hline & Retail & Japan Retail Fund, Inc & $5.09 \%$ & $-47.26 \%$ \\
\hline & Residence & TSE Residence REIT Index & $-6.62 \%$ & $-17.90 \%$ \\
\hline & Hotel & Japan Hotel REIT, Inc & $1.76 \%$ & $-57.05 \%$ \\
\hline & Healthcare & Healthcare \& Medical, Inc & $-31.77 \%$ & $-18.41 \%$ \\
\hline & REITs market & TSE REIT Index & $-1.20 \%$ & $-28.00 \%$ \\
\hline & Benchmark & Nikkei 225 & $-24.25 \%$ & $-18.48 \%$ \\
\hline
\end{tabular}

On the other hand, table 3 displays the vulnerability of U.S. and Japan REITs corporations/indices to the two stock market crashes between 2015 and 2020. The results indicate that except some non-communication tower focused U.S. infrastructure REITs corporations, the stock price of other pan-infrastructure REITs corporations in both countries outperforms that of REITs corporations in other sectors as well as benchmark indices with a relative moderate decline during the crashes, which leave us an intuition that the pan-infrastructure REITs corporations reveal more remarkable recession resistant characteristics. Therefore, such similar market performance of the pan-infrastructure REITs corporations in both U.S. and Japan during various financial crises promotes us to focus on testing the following two hypotheses in this paper:

H1: The stock price performance of pan-infrastructure REITs corporations during several financial crashes in U.S. and Japan shares considerable similarities, and we still achieve the fully understanding of pan-infrastructure REITs corporations in two countries even if without taking their respective market distinction into account.

$\mathrm{H} 2$ : The return of pan-infrastructure REITs corporations has substantial defensive characteristics regardless of its sector.

REITs whose stock price can be forecasted through various econometric methodologies during different business cycles (Li \& Chau, 2016; Li et al., 2017), in and of itself, its return has striking dual characteristics that either fluctuating along with the stock market or bringing about stable and regular dividends as bond does. In fact, there is a long on-going debate on the topic that whether a REIT is a bond or a stock. For one thing, numerous studies relying on the multi-factor model indicate that the REITs behaved as a bond in the vintage era before 1992 when the structural change of the REITs emerged, and became a stock-like asset after the overall market entered into a new era (Peterson \& Hsieh, 1997; Karolyi \& Sanders, 1998; Nelling \& Gyourko, 1998; Glascock et al., 2000; Clayton \& MacKinnon, 2001,2003; Zhu, 2018). For another thing, Liang and McIntosh employed the Sharpe model to confirm that both U.S. equity REITs and all U.S. REITs corporation index had stable return style with the integration of small cap stocks and bonds (Liang \& McIntosh, 1998). However, such researches which primarily focused on the composite REITs market failed to display the impact of sectoral effect on the corresponding REITs corpotations, let alone to corroborate the anti-volatility uniqueness of pan-infrastructure REITs market. Furthermore, the conclusion drawn by above studies only regard the time span before the breakout of global financial crisis and employ the U.S. REITs market data exclusively. Therefore, it is very crucial for us to carry out an empirical analysis based on the data in the post-global financial crisis context to investigate the stock-bond mixed features of the pan-infrastructure REITs corporations in different countries through deconstructing their return and determining the respective weights of stock and bond-related style attributes. 


\section{Data and Methodology}

In the present study, we employ the CAPM model to evaluate the stock price performance of the pan-infrastructure REITs corporations in U.S. and Japan as Eq. 1 indicated, where $r_{p}, r_{f}, r_{m}$ represents the return of relevant pan-infrastructure REITs corporation, risk-free rate and the return of benchmark index in various countries, respectively. Accordingly, Jensen alpha is the abnormal return of the corresponding REITs corporations and beta measures the corporation stock price volatility.

$$
r_{p}-r_{f}=\alpha+\beta\left(r_{m}-r_{f}\right)+\varepsilon
$$

Regarding the U.S. and Japanese market, we select the S\&P 500 and Nikkei 225 index to calculate the monthly return of the benchmark index in two countries (Ooi \& Wong, 2013).

On the other hand, we also adopt the Sharpe model to investigate the return style of the pan-infrastructure REITs corporations (Sharpe, 1992; Liang \& McIntosh, 1998). As depicted in Eq. 2, $r_{\text {large cap }}, r_{\text {mid cap }}, r_{\text {small cap }}, r_{\text {aggregate bond }}$, $r_{\text {treasury bond }}$ is the large-cap index, mid-cap index, small-cap index, aggregate bond index and risk-free rate monthly return data series, respectively; while $b_{1}, b_{2}, b_{3}, b_{4}, b_{5}$ which represent the optimum weight of corresponding asset type are fixed through solving the Eq. 2 with the assumption that short-position free and minimum variance of residual shown in Eqs.3-4.

$$
\begin{gathered}
r_{p}=b_{1} r_{\text {large cap }}+b_{2} r_{\text {mid cap }}+b_{3} r_{\text {small cap }}+b_{4} r_{\text {aggregate bond }}+b_{5} r_{\text {treasury bond }} \\
\sum_{i=1}^{5} b_{i}=1, b_{i}=0 \\
f\left(b_{i}\right)=\text { minvar }\left(r_{p}-b_{1} r_{\text {large cap }}-b_{2} r_{\text {mid cap }}-b_{3} r_{\text {small cap }}-b_{4} r_{\text {aggregate bond }}-b_{5} r_{\text {treasury bond }}\right)
\end{gathered}
$$

By analogy to the methodology proposed by Liang and McIntosh (Liang \& McIntosh, 1998), we introduce the S\&P 500 index, S\&P 400 mid cap index and S\&P small cap 600 index to acquire the monthly return of various U.S. stock markets, and the S\&P U.S. aggregate bond index and 3-month treasury bill is selected to calculate the monthly return of U.S. bond market and corresponding cash assets, respectively. On the other hand, the TSE large stock index, TSE medium stock index, TSE small stock index, S\&P Japan bond index and Japan 3-month bond yield are employed to complete the return-based style analysis of the target pan-infrastructure REITs corporations in Japan.

Besides, regarding the choice of relevant representative REITs corporations/indices in two countries, we follow two aspects of principles. If the financial institution has developed the specific REITs sector-focused index, we will select it to investigate the market performance and return style of such REITs sector market; while if such index is not available, all of the listed REITs corporation belonging to the target sector will be employed to accomplish the analysis.

Considering the more mature pan-infrastructure U.S. REITs market, NAREIT has developed the relevant industrial \& logistics and self-storage REITs sector index. In contrast, because the FTSE NAREIT data-center and infrastructure indices is only available since Jan 2016 which does not satisfy our requirement, we choose all the listed REITs corporations of these two sectors. However, for the nascent pan-infrastructure REITs market in Japan, because of the lack of specific logistics REITs and infrastructure fund index, we take most of listed logistics REITs and infrastructure fund corporations into account except some samples whose listing history are shorter than two years (i.e., two logistics REITs corporations including Itochu Advanced Logistics, Inc and Sosila Logistics REIT, Inc and three infrastructure funds covering Tokyo infra energy, Inc, Enex infra, Inc and Japan infra-fund, Inc).

Accordingly, the choice of representative other non-pan infrastructure REITs corporation/indices also satisfies the following criterion. For one thing, we will also employ the relevant REITs sector indices to research the market performance and return style of the corresponding REITs sector market as mentioned above. For another thing, if the specific REITs sector indices do not exist, the specialized REITs corporations having the highest market capitalization within the sector are chosen to represent the whole REITs sector market for analysis (i.e., the Weyerhaeuser for timberland REITs market in U.S., the Japan retail fund, Inc, Japan Hotel REIT, Inc and Healthcare and Medical, Inc represent retail, Hotel and healthcare REITs market in Japan, respectively.)

With respect to the time line of data choice process, we employ the data of aforementioned indices between Oct. 2010 and Oct. 2020 and divide them into two stages according to the variation of macroeconomic volatility. In Stage 1 from Oct 2010 to May 2015, the global market revealed significant rebounding trend after the financial crisis in 2008-2009 despite one short-lived crash appeared in Aug 2011 due to the fears of the contagion of European sovereign debt crisis; However, the outbreak of the Chinese stock market turbulence in June 2015 raised the curtain of the 1 year-lasting 2015-2016 global stock market selloff crisis. After then, the global stock 
market underwent at least three rounds of shocks successively covering the 2015-2016 stock market selloff crisis, the 2018 cryptocurrency crashes and the 2020 stock market recession stemming from the Covid-19, thus eventually resulting in a more volatile macro-environment. Accordingly, the U.S. stock market variation also follows the above trend as Fig. 1(a) indicated.

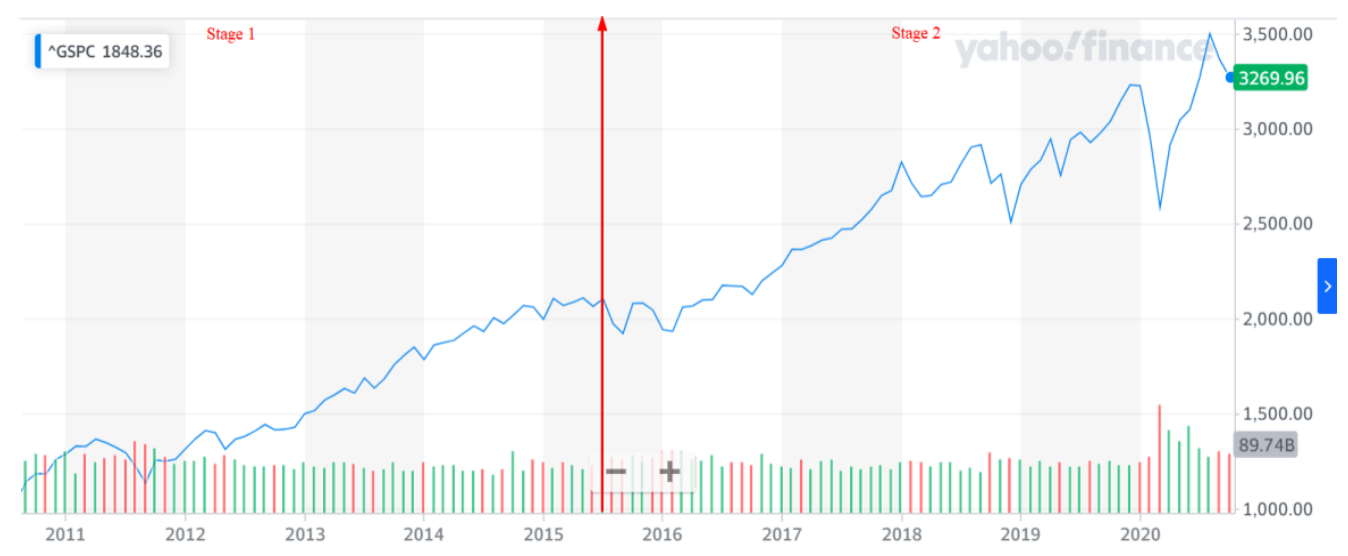

Figure 1(a). The variation of S\&P 500 index during the whole observation period. The red arrow indicates the point of time at May 2015, before which the stock market revealed a significant rebounding trend after global financial crisis; while in stage 2, the market becomes more volatile along with some uncertainty from political and economic events covering Chinese stock market crash, Brexit, U.S. presidential election, the Sino-US trade war and Covid-19

Meanwhile, the negative exogenous shock resulting from 2015-2016 selling off crisis also brought about the sharp decline of Japan stock market as fig. 1(b) denoted. Such suddenly plunge along with the substantial Japanese yen appreciation deteriorated the macroeconomic indicators considerably. In response to such recession, the Bank of Japan launched an extreme negative interest rate policy in January 2016 to stimulate the economy and fulfill the 2\% inflation rate target (Honda \& Inoue, 2019; Ito, 2021). After the implementation of this policy, the Japan REITs market experienced a new round of prosperity under the appropriate refinancing environment and its stock price variation trend also diverged from the benchmark index TOPIX gradually, which possibly induces some market distinctions during that stage which need to be further investigated.
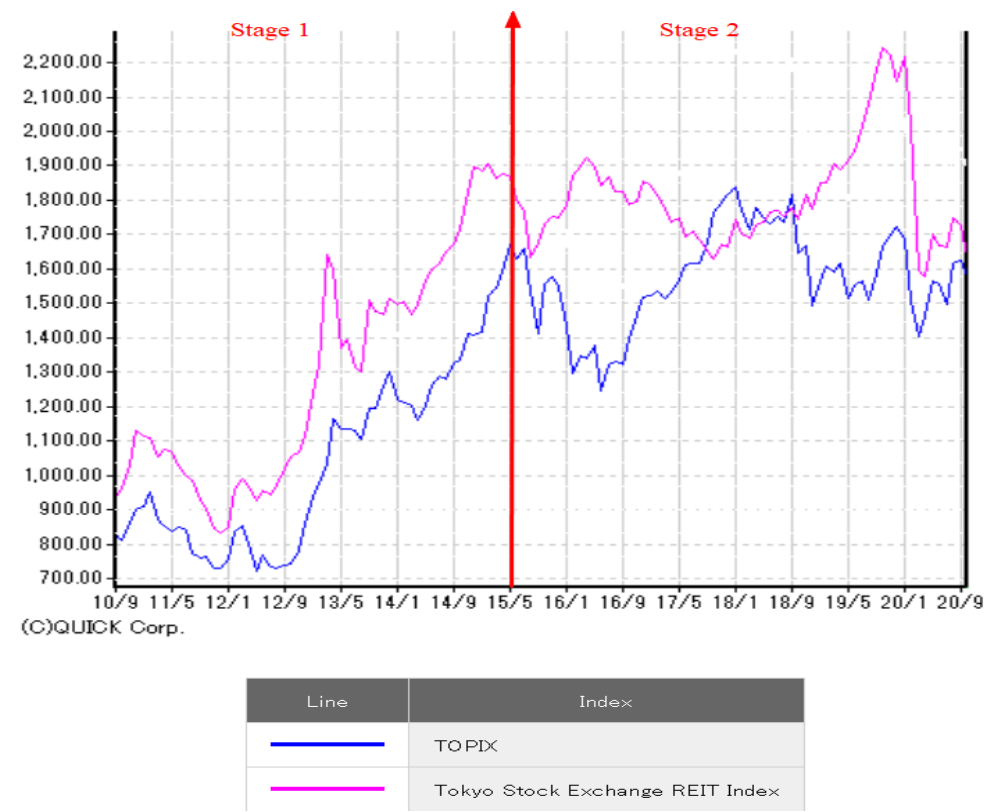

Figure 1(b). The variation trend of TOPIX and TSE REIT index, and the red arrow represents the point of time at May 2015 


\section{Results and Discussions}

\subsection{The Market Performance of Pan-Infrastructure REITs Corporations in U.S. and Japan}

Tables 4-5 illustrate the market performance of pan-infrastructure REITs corporations in U.S. and Japan. The results show that the beta value of Japanese logistics REITs corporations ranges from 0.49 to 0.62 in stage 1, which maintains at a lower level than the overall REITs market and other asset sector of REITs corporation does and denotes some resilient characteristics. While the representative logistics REITs corporations display a more remarkable defensive characteristic under the implementation of negative interest rate policy as well as the more volatile macro environment in stage 2 with a significant declining beta value lower than 0.35 , which is lower than the represent retail and hotel REITs corporation and at the same level to the office building, residential and overall REITs market index. For another thing, the stock price of infrastructure REITs corporation fluctuates more sharply than that of logistics REITs corporation with the slightly higher beta value ranging from 0.32 to 0.43. Additionally, most of pan-infrastructure REITs corporation renders a positive but not significant value of Jensen alpha and outperforms other sectors of REITs corporation in terms of the abnormal return.

On the contrary, among four types of pan-infrastructure REITs corporations in U.S. market in stage 1, the self-storage and infrastructure REITs corporations underwent the slightest fluctuation with the beta value being lower than 0.8; while the data center REITs corporations failed to exhibit the remarkable anti-volatility characteristic with the scattered results distribution of beta value between 0.77 and 1.13. Meanwhile, we also notice that the beta value of industrial \& logistics REITs corporation is at the highest level equaling to 1.44. Furthermore, most of the pan-infrastructure REITs corporation displays the positive but statistically insignificant value of Jensen alpha, which indicates the superior performance to other sectors of REITs corporation to some extent.

During the stage 2 when the macro uncertainty increased, the beta value of new infrastructure REITs corporation covering five data center REITs corporation and three communication tower focused infrastructure REITs corporation dropped significantly ranging between -0.59 and 0.58 , which exhibits the substantial anti-volatility characteristic. On the other hand, the considerably declining beta value of self-storage REITs market verifies its most remarkable defensive characteristic, and the industrial \& logistics REITs market is still more volatile than the overall REITs market in spite of its sharply decreased beta value from 1.44 to 0.82 . Besides, accompanying with the intensified geo-conflict and political risk, the stock price of other three infrastructure REITs corporations which belongs to the public utility sub-sector covering UNITI corporation which engages in the acquisition and construction of the communication distribution system, the CORR which focuses on the energy infrastructure and the LMRK whose business includes the land leasing of wireless communication, outdoor advertising and renewable power generation properties, undergoes sharply fluctuation and weak form of anti-volatility characteristic along with the beta value ranging from 0.97 to 1.17 that being at the higher level in the whole industry. Finally, the abnormal return of pan-infrastructure REITs corporations reveals substantial differentiation that although the Jensen alpha of data center and communication tower REITs corporation is insignificantly positive, it still not only outperforms the self-storage REITs and other three infrastructure REITs corporations but also is superior to that of the traditional office building, retail and hotel REITs corporations.

However, according to the horizontal comparison analysis, the beta value of pan-infrastructure REITs corporation in Japan is much lower than the counterparts in U.S covering industrial and logistics REITs corporations as well as the three other infrastructure REITs corporations: UNITI, LMRK and CORR thereinbefore which contradicts with the hypothesis 1 that the stock price performance of pan-infrastructure REITs corporations in U.S. and Japan share huge similarities during a volatile macro-environment that needs not to be further investigated. Such difference can be ascribed to three aspects of reasons. Firstly, the underlying assets of Japanese pan-infrastructure REITs corporations are mainly concentrated on domestic market, which is not so susceptible to the global macro-environment variation as U.S. pan-infrastructure corporation is. Secondly, the Tokyo stock exchange establish the independent infrastructure fund and REIT section resulting in the exclusiveness of relevant trading behavior. At last, the negative interest rate policy implemented by bank of Japan promotes the new round prosperity of J-REITs market. 
Table 4(a). The market performance of pan-infrastructure REITs corporations in Japan in stage 1, where (*), (**) and $(* * *)$ denotes the significance at the $10 \%, 5 \%$ and $1 \%$ level, respectively

\begin{tabular}{llll}
\hline Pan-infrastructure REITs & & & \\
\hline Asset sector & Corporation/index name & Beta & Jensen Alpha \\
& Japan Logistics Fund & $0.49(* * *)$ & $0.50 \%$ \\
Representative logistics REITs corporations & Industrial Investment Fund & $0.53(* * *)$ & $1.62 \%(*)$ \\
& GLP Investment Corporation & $0.62(* *)$ & $0.81 \%$ \\
\hline Other REITs sector & & & \\
\hline Office building REITs & TSE Office REIT & $0.67(* * *)$ & $0.23 \%$ \\
Representative retail REITs & Japan Retail Fund, Inc & $0.58(* * *)$ & $0.65 \%$ \\
Residential REITs & TSE Residence REIT & $0.57(* * *)$ & $0.79 \%$ \\
Representative hotel REITs & Japan Hotel REIT, Inc & $0.75(* * *)$ & $1.64 \%(*)$ \\
Overall REITs market & TSE REITs & $0.62(* * *)$ & $0.42 \%$ \\
\hline
\end{tabular}

Table 4(b). The market performance of Japanese pan-infrastructure REITs corporations in stage 2

\begin{tabular}{llll}
\hline Pan-infrastructure REITs & & & \\
\hline Asset sector & Corporation/index name & Beta & Jensen Alpha \\
& Japan Logistics Fund & $0.23(* *)$ & $0.36 \%$ \\
& Industrial Investment Fund & $0.30(* *)$ & $0.46 \%$ \\
Representative logistics REITs corporations & GLP Investment Corporation & $0.21(*)$ & $0.63 \%$ \\
& Lasalle Logiport REITs, Inc & $0.26(*)$ & $0.84 \%$ \\
& CRE Logistics REITs & $0.35(*)$ & $1.22 \%$ \\
\hline \multirow{2}{*}{ Representative } & Takara Leben Infrastructure Fund & $0.32(* *)$ & $-0.06 \%$ \\
corporations & REITs & Ichigo Green Infrastructure Fund & $0.58 \%$ \\
& Renewable Japan Energy Fund, Inc & $0.39(* * *)$ & $0.58 \%$ \\
\hline Other REITs sector & Canadian Solar Infrastructure Fund, Inc & $0.43(* * *)$ & $0.43 \%$ \\
\hline Office building REITs & & $0.33(* * *)$ & $1.02 \%(*)$ \\
Representative retail REITs & TSE Office REIT & $0.33(* * *)$ & $-0.17 \%$ \\
Residential REITs & Japan Retail Fund, Inc & $0.53(* * *)$ & $-0.53 \%$ \\
Representative healthcare REITs & TSE Residence REIT & $0.26(* * *)$ & $0.17 \%$ \\
Representative hotel REITs & Healthcare \& Medical, Inc & $0.43(* * *)$ & $0.29 \%$ \\
Overall REITs market & Japan Hotel REIT,Inc & $1.07(* * *)$ & $-0.58 \%$ \\
\hline
\end{tabular}

Table 5(a). The market performance of pan-infrastructure REITs corporation in U.S. REITs market in stage 1

\begin{tabular}{llll}
\hline Pan-infrastructure REITs corporation & & & Jensen Alpha \\
\hline Asset sectors & Corporation/index name & Beta & $1.15 \%$ \\
& Equinix & $0.77(* * *)$ & $0.87 \%$ \\
Representative data center REITs & COR & $1.13(* * *)$ & $0.46 \%$ \\
& Cyrusone & $0.98(* *)$ & $0.78 \%$ \\
Representative infrastructure REITs & AMT & $(-0.73)(* * *)$ & $0.77 \%$ \\
& CCI & $0.34(* * *)$ & $1.20 \%(*)$ \\
Industrial \& logistics REITs & SBAC & $0.64(* * *)$ & $-0.63 \%$ \\
Self-Storage REITs & FTSE NAREIT Industrial & $1.44(* * *)$ & $0.81 \%$ \\
\hline Other REITs sector & FTSE NAREIT Self Storage & $0.69(* * *)$ & $-0.40 \%$ \\
\hline Office building REITs & & & $0.10 \%$ \\
Retail REITs & FTSE NAREIT Office & $0.87(* * *)$ & $0.29 \%$ \\
Residential REITs & FTSE NAREIT Retail & $0.83(* * *)$ & $-0.79 \%$ \\
Hotel REITs & FTSE NAREIT Residential & $0.57(* * *)$ & $-0.39 \%$ \\
Diversified REITs & FTSE NAREIT Lodging/Resorts & $1.58(* * *)$ & $-0.03 \%$ \\
Representative Timberland REITs corporation & FTSE NAREIT Diversified & $0.80(* * *)$ & $-0.03 \%$ \\
Healthcare REITs & FTSE NAREIT Healthcare & $1.37(* * *)$ & $0.00 \%$ \\
Specialty REITs & Dow Jones Specialty REITs & $0.67(* * *)$ & $-0.11 \%$ \\
Overall REITs market & FTSE NAREIT All Equity REITs & $0.83(* * *)$ & \\
\hline
\end{tabular}


Table 5(b). The market performance of pan-infrastructure REITs corporation in U.S. REITs market in stage 2

\begin{tabular}{llll}
\hline Pan-infrastructure REITs corporation & & & \\
\hline Asset sectors & Corporation/index name & Beta & Jensen Alpha \\
& Equinix & $0.51(* *)$ & $0.86 \%$ \\
& DLR & $0.32(*)$ & $0.41 \%$ \\
Representative data center REITs & COR & $0.37(*)$ & $0.72 \%$ \\
& QTS & $0.58(* *)$ & $0.20 \%$ \\
& Cyrusone & $0.58(* * *)$ & $0.63 \%$ \\
& AMT & $(-0.59)(* * *)$ & $0.60 \%$ \\
& CCI & $0.35(* * *)$ & $0.16 \%$ \\
Representative infrastructure REITs & SBAC & $0.38(* *)$ & $0.73 \%$ \\
& CORR & $1.17(* * *)$ & $-2.54 \%$ \\
Industrial \& logistics REITs & UNITI & $1.01(* *)$ & $-1.09 \%$ \\
Self-Storage REITs & LMRK & $0.97(* * *)$ & $-1.14 \%$ \\
Other REITs sector & FTSE NAREIT Industrial & $0.82(* * *)$ & $0.60 \%$ \\
\hline Office building REITs & FTSE NAREIT Self Storage & $0.25(*)$ & $-0.43 \%$ \\
Retail REITs & & & $(-1.13 \%)(* *)$ \\
Residential REITs & FTSE NAREIT Office & $(-1.54 \%)(* *)$ \\
Hotel REITs & FTSE NAREIT Retail & $0.91(* * *)$ & $-0.57 \%$ \\
Diversified REITs & FTSE NAREIT Residential & $1.03(* * *)$ & $(-1.66 \%)(* *)$ \\
Representative Timberland REITs corporation $)$ & $0.66(* * *)$ & $(-1.41 \%)(* *)$ \\
Healthcare REITs & FTSE NAREIT Lodging/Resorts & $1.35(* * *)$ & $-0.30 \%$ \\
Specialty REITs & FTSE NAREIT Diversified & $1.04(* * *)$ & $-0.98 \%$ \\
Overall REITs market & FTSE NAREIT Healthcare & $1.90(* * *)$ & $-0.25 \%$ \\
\hline & Dow Jones Specialty REITs & $0.78(* * *)$ & $(-0.66 \%)(*)$ \\
\hline
\end{tabular}

\subsection{The Return Style Analysis of Pan-Infrastructure REITs Corporations in U.S. and Japan}

Tables.6-7 show the return style of the pan-infrastructure REITs corporations in U.S. and Japan. In stage 1, the return style of logistics REITs corporations in Japan is the combination of small-cap stock and aggregate bond, and the small-cap stock accounts for at least $30 \%$ weight of the style attributes, which is in accordance with the fact that both the logistics REITs corporations and J-REITs market underwent a higher growth during this stage especially after December 2012 when the Abenomics took effect.

However, the style transformation appeared that the Japan logistics REITs corporations exhibited strong defensive characteristics with the substantially increasing ratio of aggregate bond attributes exceeding $68 \%$ during stage 2 along with the implementation of negative interest rate policy. Meanwhile, we also notice that the ratio of aggregated bond attributes in three logistics REITs corporations covering the Nippon Prologis REIT, Inc, Mitsui Fudosan Logistics Park, Inc and Mitsubishi Estate Logistics REIT exceeds 85\%, which is much higher than that in other five logistics REITs corporations. Such firm-specific distinctions may be ascribed to several aspect of reasons. Firstly, the above three logistics REITs corporations have sponsors with an abundant real estate operating expertise and stable property support pipeline as Table 8 signified (the sponsor of former one is Prologis which is the biggest logistics REITs in the world, while that of latter two is the Mitsui Fudosan and Mitsubishi Estate, respectively, which is the largest two developers in Japan). Secondly, the above three corporations have higher refinancing capacity with a lower debt financing cost due to their stronger sponsor, which contributes to the higher ratio of bond attributes.

On the other hand, regarding the infrastructure fund corporations, we find that the aggregate bond attributes account for a lower ratio of its return style than those logistics REITs corporations established over the same period. In fact, according to the descriptive statistics shown in the Table 9, the smaller asset size as well as the higher leverage ratio will lead to the infrastructure fund corporations suffering from the highest debt cost and limited debt financing activity, which forces them to attract the investors through highest level of dividend yield and become more equity financing preferred, thus eventually results in a higher weight of stock-related style attributes than the logistics REITs corporations. In addition, after comparing the corresponding results with various sectors of REITs corporations, we notice that the ratio of bond attributes in logistics REITs corporations is at the same level as in residential REITs corporations, both of which are much higher than those in office building REITs corporations and composite REITs market and exhibit higher degree of earnings stability.

In contrast, the return style of pan-infrastructure REITs corporations in U.S. market varies a lot from one asset sector to another. During stage 1 , the mid-cap stock is the main attributes to compose the return style of 
industrial \& logistics REITs corporations, self-storage REITs corporations and several data center REITs corporations, which coincides with the fact that the above sectoral REITs market still had some growing space during that stage. However, thanks to the established market competition situation, the return style of three large-sized communication tower focused infrastructure REITs corporations covering AMT, CCI and SBAC is the integration of large cap stock and aggregate bond and reveals some specific defensive characteristics.

In stage 2 being filled with macro uncertainty, the return style of pan-infrastructure REITs corporations also displays some variation comparing with stage 1 . For one thing, the aggregated bond attributes become the core factor to influence the return style of both data center and self-storage REITs corporations with the significantly declined ratio of mid-cap stock attributes. For another thing, the return style of industrial \& logistics REITs corporations achieves the transformation from the exclusiveness of mid cap stock to the combination between large-cap stock and aggregate bond. Accordingly, the fact that stock constituents account for higher ratio of return style in industrial \& logistics REITs corporations which coincides with the aforementioned results that the beta value of such type of REITs corporation maintaining at a higher level among various types of pan-infrastructure corroborates a conclusion that the industrial \& logistics facilities maybe not an appropriate type of asset for anti-volatility under a more volatile macro environment.

In addition, the return style of infrastructure REITs corporations appears remarkable differentiation. On one hand, the three large sized cell tower focused infrastructure REITs corporations maintain a stable return style as they did in stage 1. On the other hand, the mid or small cap stock constituents comprise the main style attributes of three other infrastructure REITs corporations which belong to the public utility sub-sector with lower ratio of aggregated bond attributes, which renders a weaker anti-volatility characteristic.

After comparing the return style of industrial \& logistics REITs corporation and infrastructure fund corporations in Japan with the counterparts in U.S. market, we find the return style of corresponding pan-infrastructure REITs corporations in two countries differs substantially that the former reveals more remarkable earnings stability with higher ratio of aggregated bond attributes while the latter exhibits higher volatility with larger ratio of stock constituents. Being coherent with the aforementioned assumption, we still attribute such difference to the different financing preference of the pan-infrastructure REITs corporations between two countries. In fact, after the implementation of the extreme negative interest rate policy in January 2016 during stage 2, the debt-cost of the J-REITs market underwent a further decline as Table 10 indicated. Such circumstance promotes the industrial and logistics REITs corporations which share the lowest averaged debt cost about $0.65 \%$ to become more debt financing preferred, thus resulting in a much more significant bond-like behavior than the counterparts in U.S. market whose dividend yield are comparable to the debt cost as Table 11 displayed. Accordingly, the similar case is also applicable to explain that why the solar power focused Japan infrastructure fund corporations have higher weight of bond attributes than the corresponding public-utility sector U.S. infrastructure REITs corporations do.

Overall, the above findings confirm the necessity of sectoral effect for determining the return style of pan-infrastructure REITs corporations in both U.S. and Japan, which rejects the second hypothesis that the pan-infrastructure REITs corporations in both countries render substantial defensive characteristics regardless of their asset sectors.

Table 6(a). The return style of the Japanese pan-infrastructure REITs corporation and the comparison with other sector REITs corporations in stage 1

\begin{tabular}{|c|c|c|c|c|c|c|}
\hline \multicolumn{7}{|l|}{ Pan-infrastructure REITs corporation } \\
\hline Asset Sector & $\begin{array}{l}\text { Representative } \\
\text { corporation/index }\end{array}$ & $\begin{array}{c}\text { Large cap } \\
\text { stock weight }\end{array}$ & $\begin{array}{l}\text { Mid cap stock } \\
\text { weight }\end{array}$ & $\begin{array}{c}\text { Small cap } \\
\text { stock weight }\end{array}$ & $\begin{array}{l}\text { Aggregated } \\
\text { bond weight }\end{array}$ & $\begin{array}{c}\text { Risk-free } \\
\text { rate weight }\end{array}$ \\
\hline \multirow{4}{*}{ Representative logistics REITs corporation } & Japan Logistics Fund & $0.42 \%$ & $1.79 \%$ & $55.88 \%$ & $41.62 \%$ & $0.28 \%$ \\
\hline & Industrial Investment Fund & $23.63 \%$ & $0.28 \%$ & $32.30 \%$ & $43.46 \%$ & $0.32 \%$ \\
\hline & GLP Investment Corporation & $0.08 \%$ & $0.11 \%$ & $95.94 \%$ & $3.70 \%$ & $0.17 \%$ \\
\hline & Nippon Prologis REIT & $0.00 \%$ & $0.01 \%$ & $46.14 \%$ & $53.84 \%$ & $0.01 \%$ \\
\hline \multicolumn{7}{|l|}{ Other sector REITs corporation } \\
\hline Overall J-REITs market & TSE REIT index & $11.20 \%$ & $2.87 \%$ & $56.39 \%$ & $29.49 \%$ & $0.05 \%$ \\
\hline Office buildings REITs market & TSE Office REIT index & $12.77 \%$ & $5.01 \%$ & $58.05 \%$ & $23.96 \%$ & $0.21 \%$ \\
\hline Representative retail REITs corporation & Japan Retail Fund, Inc & $1.61 \%$ & $49.67 \%$ & $16.83 \%$ & $31.65 \%$ & $0.23 \%$ \\
\hline Representative hotel REITs corporation & Japan Hotel REIT, Inc & $35.36 \%$ & $11.37 \%$ & $28.41 \%$ & $24.65 \%$ & $0.21 \%$ \\
\hline Residential REITs market & TSE Residential REIT index & $6.74 \%$ & $0.46 \%$ & $57.43 \%$ & $35.09 \%$ & $0.29 \%$ \\
\hline
\end{tabular}


Table 6(b). The return style of Japanese pan-infrastructure REITs corporation and the comparison with other sector REITs corporation in stage 2

\begin{tabular}{|c|c|c|c|c|c|c|}
\hline \multicolumn{7}{|c|}{ Pan-infrastructure REITs corporation } \\
\hline Asset Sector & Representative corporation/index & $\begin{array}{c}\text { Large cap } \\
\text { stock weight }\end{array}$ & $\begin{array}{c}\text { Mid cap stock } \\
\text { weight }\end{array}$ & $\begin{array}{c}\text { Small cap } \\
\text { stock weight }\end{array}$ & $\begin{array}{l}\text { Aggregated } \\
\text { bond weight }\end{array}$ & $\begin{array}{c}\text { Risk-free } \\
\text { rate weight }\end{array}$ \\
\hline \multirow{8}{*}{$\begin{array}{l}\text { Representative logistics } \\
\text { REITs corporation }\end{array}$} & Japan Logistics Fund & $5.17 \%$ & $14.58 \%$ & $0.16 \%$ & $80.01 \%$ & $0.09 \%$ \\
\hline & Industrial Investment Fund & $10.83 \%$ & $15.49 \%$ & $0.43 \%$ & $73.00 \%$ & $0.25 \%$ \\
\hline & GLP Investment Corporation & $0.97 \%$ & $16.89 \%$ & $0.14 \%$ & $81.72 \%$ & $0.28 \%$ \\
\hline & Nippon Prologis REIT & $6.07 \%$ & $0.99 \%$ & $0.07 \%$ & $92.81 \%$ & $0.06 \%$ \\
\hline & Lasalle Logiport, Inc & $5.06 \%$ & $0.89 \%$ & $18.36 \%$ & $75.07 \%$ & $0.62 \%$ \\
\hline & Mitsui Fudosan Logistics Park & $0.61 \%$ & $12.69 \%$ & $0.45 \%$ & $85.83 \%$ & $0.42 \%$ \\
\hline & Mitsubishi Estate Logistics REIT & $4.20 \%$ & $0.04 \%$ & $0.19 \%$ & $95.50 \%$ & $0.07 \%$ \\
\hline & CRE Logistics & $0.36 \%$ & $0.04 \%$ & $30.94 \%$ & $68.60 \%$ & $0.05 \%$ \\
\hline \multirow{4}{*}{$\begin{array}{l}\text { Representative } \\
\text { infrastructure } \\
\text { corporations }\end{array}$} & Takara Leben Infrastructure Fund & $0.60 \%$ & $14.47 \%$ & $18.69 \%$ & $65.68 \%$ & $0.56 \%$ \\
\hline & Ichigo Green Infrastructure Fund & $38.46 \%$ & $1.82 \%$ & $8.32 \%$ & $47.71 \%$ & $3.69 \%$ \\
\hline & $\begin{array}{l}\text { Renewable Japan Energy } \\
\text { Infrastructure Fund }\end{array}$ & $1.25 \%$ & $42.73 \%$ & $1.58 \%$ & $48.52 \%$ & $5.92 \%$ \\
\hline & Canadian Solar Infrastructure Fund & $5.62 \%$ & $29.72 \%$ & $1.42 \%$ & $61.25 \%$ & $1.99 \%$ \\
\hline \multicolumn{7}{|c|}{ Other sector REITs corporation } \\
\hline Overall J-REITs market & TSE REIT index & $25.72 \%$ & $8.04 \%$ & $0.08 \%$ & $66.15 \%$ & $0.01 \%$ \\
\hline $\begin{array}{l}\text { Office buildings REITs } \\
\text { market }\end{array}$ & TSE Office REIT index & $29.06 \%$ & $4.92 \%$ & $0.30 \%$ & $65.49 \%$ & $0.23 \%$ \\
\hline $\begin{array}{l}\text { Representative retail REITs } \\
\text { corporation }\end{array}$ & Japan Retail Fund, Inc & $0.26 \%$ & $53.55 \%$ & $0.86 \%$ & $45.15 \%$ & $0.18 \%$ \\
\hline $\begin{array}{l}\text { Representative healthcare } \\
\text { REITs corporation }\end{array}$ & Healthcare \& Medical, Inc & $38.46 \%$ & $0.67 \%$ & $6.36 \%$ & $54.08 \%$ & $0.42 \%$ \\
\hline $\begin{array}{l}\text { Representative hotel } \\
\text { corporation }\end{array}$ & Japan Hotel REIT, Inc & $81.64 \%$ & $16.92 \%$ & $0.21 \%$ & $1.09 \%$ & $0.15 \%$ \\
\hline Residential REITs market & TSE Residential REIT index & $17.97 \%$ & $7.63 \%$ & $0.85 \%$ & $73.53 \%$ & $0.02 \%$ \\
\hline
\end{tabular}

Table 7(a). The return style of U.S. pan-infrastructure REITs corporation and the comparison with other sector REITs corporation during stage 1

\begin{tabular}{|c|c|c|c|c|c|c|}
\hline \multicolumn{7}{|l|}{ Pan-infrastructure REITs corporation } \\
\hline Asset sector & $\begin{array}{l}\text { Representative } \\
\text { corporation/index }\end{array}$ & $\begin{array}{c}\text { Large cap } \\
\text { stock weight }\end{array}$ & $\begin{array}{c}\text { Mid cap } \\
\text { stock weigh }\end{array}$ & $\begin{aligned} & \text { Small cap } \\
& \text { stock weight }\end{aligned}$ & $\begin{array}{l}\text { Aggregated } \\
t \text { bond weight }\end{array}$ & $\begin{array}{l}\text { Risk-free } \\
\text { rate weight }\end{array}$ \\
\hline \multirow{6}{*}{$\begin{array}{l}\text { Representative data center REITs } \\
\text { corporation }\end{array}$} & Equinix & $41.49 \%$ & $29.32 \%$ & $0.11 \%$ & $28.55 \%$ & $0.53 \%$ \\
\hline & DLR & $9.35 \%$ & $15.31 \%$ & $0.12 \%$ & $75.08 \%$ & $0.13 \%$ \\
\hline & $\mathrm{COR}$ & $0.09 \%$ & $86.10 \%$ & $0.41 \%$ & $13.41 \%$ & $0.00 \%$ \\
\hline & QTS & $0.02 \%$ & $76.39 \%$ & $0.04 \%$ & $23.53 \%$ & $0.03 \%$ \\
\hline & Cyrusone & $0.57 \%$ & $80.36 \%$ & $0.20 \%$ & $18.71 \%$ & $0.16 \%$ \\
\hline & AMT & $22.47 \%$ & $0.06 \%$ & $0.02 \%$ & $77.45 \%$ & $0.01 \%$ \\
\hline Representative infrastructure & $\mathrm{CCI}$ & $29.40 \%$ & $0.10 \%$ & $0.02 \%$ & $70.47 \%$ & $0.01 \%$ \\
\hline \multirow[t]{2}{*}{ REITs corporation } & SBAC & $58.51 \%$ & $0.25 \%$ & $0.09 \%$ & $40.89 \%$ & $0.26 \%$ \\
\hline & CORR & $37.49 \%$ & $9.90 \%$ & $0.29 \%$ & $51.93 \%$ & $0.39 \%$ \\
\hline Self-Storage REITs market & FTSE NAREIT Self Storage & $0.41 \%$ & $55.58 \%$ & $0.29 \%$ & $43.57 \%$ & $0.15 \%$ \\
\hline Industrial \& logistics REITs market & FTSE NAREIT Industrial & $0.06 \%$ & $92.45 \%$ & $7.46 \%$ & $0.02 \%$ & $0.01 \%$ \\
\hline \multicolumn{7}{|l|}{ Other sector REITs corporation } \\
\hline Office building REITs market & FTSE NAREIT Office & $0.83 \%$ & $68.45 \%$ & $0.50 \%$ & $30.05 \%$ & $0.17 \%$ \\
\hline Retail REITs market & FTSE NAREIT Retail & $0.26 \%$ & $64.11 \%$ & $0.04 \%$ & $35.56 \%$ & $0.01 \%$ \\
\hline Residential REITs market & FTSE NAREIT Residential & $0.24 \%$ & $47.18 \%$ & $2.15 \%$ & $50.27 \%$ & $0.16 \%$ \\
\hline Hotel REITs market & FTSE NAREIT Lodging/Resorts & ts $0.23 \%$ & $34.96 \%$ & $64.79 \%$ & $0.01 \%$ & $0.01 \%$ \\
\hline Diversified REITs market & FTSE NAREIT Diversified & $7.00 \%$ & $56.10 \%$ & $0.29 \%$ & $36.42 \%$ & $0.17 \%$ \\
\hline $\begin{array}{l}\text { Representative timberland REITs } \\
\text { corporation }\end{array}$ & Weyerhaeuser & $23.35 \%$ & $76.53 \%$ & $0.09 \%$ & $0.01 \%$ & $0.01 \%$ \\
\hline Healthcare REITs market & FTSE NAREIT Healthcare & $0.34 \%$ & $34.94 \%$ & $0.22 \%$ & $64.39 \%$ & $0.11 \%$ \\
\hline Specialty REITs market & Dow Jones Specialty REITs & $8.06 \%$ & $43.29 \%$ & $0.20 \%$ & $48.30 \%$ & $0.15 \%$ \\
\hline Overall U.S. REITs market & FTSE NAREIT All Equity REITs & Ts $1.24 \%$ & $63.72 \%$ & $0.35 \%$ & $34.54 \%$ & $0.15 \%$ \\
\hline
\end{tabular}


Table 7(b). The return style of U.S. pan-infrastructure REITs corporations and the comparison with other REITs sector corporations in stage 2

\begin{tabular}{|c|c|c|c|c|c|c|}
\hline \multicolumn{7}{|l|}{ Pan-infrastructure REITs corporation } \\
\hline Asset sector & $\begin{array}{l}\text { Representative } \\
\text { corporation/index }\end{array}$ & $\begin{array}{c}\text { Large cap } \\
\text { stock weight }\end{array}$ & $\begin{array}{c}\text { Mid cap } \\
\text { stock weight }\end{array}$ & $\begin{array}{c}\text { Small cap } \\
\text { stock weight }\end{array}$ & $\begin{array}{l}\text { Aggregated } \\
\text { bond weight }\end{array}$ & $\begin{array}{l}\text { Risk-free } \\
\text { rate weight }\end{array}$ \\
\hline \multirow{5}{*}{$\begin{array}{l}\text { Representative data center REITs } \\
\text { corporation }\end{array}$} & Equinix & $39.24 \%$ & $0.01 \%$ & $0.00 \%$ & $60.74 \%$ & $0.01 \%$ \\
\hline & DLR & $19.69 \%$ & $0.02 \%$ & $0.01 \%$ & $80.28 \%$ & $0.00 \%$ \\
\hline & COR & $19.50 \%$ & $0.48 \%$ & $0.07 \%$ & $79.89 \%$ & $0.06 \%$ \\
\hline & QTS & $4.50 \%$ & $33.18 \%$ & $0.01 \%$ & $62.31 \%$ & $0.00 \%$ \\
\hline & Cyrusone & $39.18 \%$ & $0.01 \%$ & $0.00 \%$ & $60.80 \%$ & $0.01 \%$ \\
\hline \multirow{6}{*}{$\begin{array}{l}\text { Representative infrastructure REITs } \\
\text { corporation }\end{array}$} & AMT & $32.60 \%$ & $0.10 \%$ & $0.04 \%$ & $67.08 \%$ & $0.18 \%$ \\
\hline & $\mathrm{CCI}$ & $26.10 \%$ & $0.00 \%$ & $0.00 \%$ & $73.89 \%$ & $0.01 \%$ \\
\hline & SBAC & $29.38 \%$ & $0.01 \%$ & $0.00 \%$ & $70.60 \%$ & $0.01 \%$ \\
\hline & CORR & $0.03 \%$ & $0.02 \%$ & $99.89 \%$ & $0.02 \%$ & $0.04 \%$ \\
\hline & UNITI & $0.00 \%$ & $80.19 \%$ & $0.00 \%$ & $19.80 \%$ & $0.00 \%$ \\
\hline & LMRK & $0.27 \%$ & $83.73 \%$ & $0.02 \%$ & $15.83 \%$ & $0.15 \%$ \\
\hline Self-storage REITs market & FTSE NAREIT Self Storage & $2.54 \%$ & $14.66 \%$ & $0.38 \%$ & $82.06 \%$ & $0.36 \%$ \\
\hline Industrial \& logistics REITs market & FTSE NAREIT Industrial & $62.94 \%$ & $10.58 \%$ & $0.36 \%$ & $25.95 \%$ & $0.18 \%$ \\
\hline \multicolumn{7}{|l|}{ Other sector REITs corporation } \\
\hline Office building REITs market & FTSE NAREIT Office & $34.75 \%$ & $5.79 \%$ & $39.73 \%$ & $19.28 \%$ & $0.45 \%$ \\
\hline Retail REITs market & FTSE NAREIT Retail & $3.15 \%$ & $24.44 \%$ & $56.07 \%$ & $16.34 \%$ & $0.01 \%$ \\
\hline Residential REITs market & FTSE NAREIT Residential & $0.99 \%$ & $53.11 \%$ & $0.02 \%$ & $45.87 \%$ & $0.02 \%$ \\
\hline Hotel REITs market & FTSE NAREIT Lodging/Resorts & s $\quad 0.02 \%$ & $1.14 \%$ & $98.82 \%$ & $0.01 \%$ & $0.01 \%$ \\
\hline Diversified REITs market & FTSE NAREIT Diversified & $32.00 \%$ & $10.67 \%$ & $46.70 \%$ & $10.58 \%$ & $0.04 \%$ \\
\hline Representative timberland REITs market & Weyerhaeuser & $0.49 \%$ & $50.39 \%$ & $49.09 \%$ & $0.02 \%$ & $0.01 \%$ \\
\hline Healthcare REITs market & FTSE NAREIT Healthcare & $0.06 \%$ & $62.73 \%$ & $0.07 \%$ & $37.12 \%$ & $0.02 \%$ \\
\hline Specialty REITs market & Dow Jones Specialty REITs & $40.59 \%$ & $8.48 \%$ & $0.03 \%$ & $50.87 \%$ & $0.03 \%$ \\
\hline Overall U.S. REITs market & FTSE NAREIT All Equity REITs & s $21.36 \%$ & $42.01 \%$ & $0.60 \%$ & $35.79 \%$ & $0.24 \%$ \\
\hline
\end{tabular}

Table 8. The sponsor and debt cost of 8 Japan logistics REITs corporations in FY 2020.

\begin{tabular}{|c|c|c|c|}
\hline Logistics REITs Corporation & Sponsor & Sponsor Characteristics & $\begin{array}{l}\text { Debt cost in } \\
\text { FY } 2020\end{array}$ \\
\hline Mitsui Fudosan Logistics Park, Inc & Mitsui Fudosan Co., Ltd & One of the largest real estate developers in Japan & $0.33 \%$ \\
\hline Mitsubishi Estate Logistics REIT, Inc & Mitsubishi Estate Co., Ltd & One of the largest real estate developers in Japan & $0.44 \%$ \\
\hline Nippon Prologis REIT, Inc & Prologis & The largest logistics REIT in the world & $0.63 \%$ \\
\hline Japan Logistics Fund, Inc & Mitsui \& Co., Ltd & One of the largest general trading in Japan & $0.68 \%$ \\
\hline GLP, Inc & GLP & $\begin{array}{l}\text { A global leading logistics providers whose scale is } \\
\text { smaller than Prologis }\end{array}$ & $0.72 \%$ \\
\hline Lasalle Logiport, Inc & Lasalle Group & One of the largest real estate private fund in the world & $0.85 \%$ \\
\hline CRE Logistics Fund, Inc & CRE, Inc & $\begin{array}{l}\text { The small-sized logistics facilities developer and leseer } \\
\text { in Japan }\end{array}$ & $0.96 \%$ \\
\hline Industrial Infrastructue Fund, Inc & $\begin{array}{l}\text { Mitsubishi Corp UBS } \\
\text { Realty }\end{array}$ & $\begin{array}{l}\text { An asset manager as a joint venture between Mitsubishi } \\
\text { Corp and UBS A.G. }\end{array}$ & $1.01 \%$ \\
\hline
\end{tabular}

Table 9. The financial indicators of various sector REITs market in Japan. The latest monthly data in October 2021 is employed. Meanwhile, the annualized growth rate is obtained through calculating the quotient between the market cap of various REITs sector markets in Dec 2009 and in Oct 2021, while such data fails to be acquired for the nascent infrastructure fund and healthcare REITs market due to their short-listed history from 2015

\begin{tabular}{|c|c|c|c|c|c|c|}
\hline Sector & $\begin{array}{c}\text { Average Asset } \\
\text { Size (Billion yen) }\end{array}$ & $\begin{array}{c}\text { Average Leverage } \\
\text { Ratio }\end{array}$ & $\begin{array}{c}\text { Average } \\
\text { Dividend Yield }\end{array}$ & $\begin{array}{c}\text { Average listing } \\
\text { age (year) }\end{array}$ & $\begin{array}{l}\text { Annualized } \\
\text { growth rate }\end{array}$ & $\begin{array}{l}\text { Averaged } \\
\text { debt cost }\end{array}$ \\
\hline Office Building & 443.94 & $45.19 \%$ & $4.02 \%$ & 14.14 & $11.30 \%$ & $0.79 \%$ \\
\hline Residence & 258.18 & $49.98 \%$ & $3.52 \%$ & 11.62 & $13.33 \%$ & $0.83 \%$ \\
\hline Retail & 404.3 & $39.45 \%$ & $4.20 \%$ & 12.62 & $7.05 \%$ & $0.80 \%$ \\
\hline Hotel & 205.35 & $43.73 \%$ & $1.90 \%$ & 9.53 & $37.54 \%$ & $1.14 \%$ \\
\hline Healthcare & 67.1 & $48.10 \%$ & $4.15 \%$ & 6.65 & - & $0.91 \%$ \\
\hline Diversified & 365.83 & $45.44 \%$ & $4.18 \%$ & 11.17 & $18.59 \%$ & $0.85 \%$ \\
\hline Logistics & 332.39 & $39.58 \%$ & $3.02 \%$ & 6.47 & $33.87 \%$ & $0.69 \%$ \\
\hline Infrastructure & 42.67 & $52.42 \%$ & $5.90 \%$ & 3.81 & - & $1.30 \%$ \\
\hline
\end{tabular}


Table 10. The average debt cost of various sector Japan REITs corporations in FY 2015 and FY 2020. Meanwhile, the data of Japan infrastructure fund market in FY 2015 is not available because such market is newly developed since 2015

\begin{tabular}{lll}
\hline Sector & FY 2015 & FY2020 \\
\hline Office Building & $1.31 \%$ & $0.79 \%$ \\
Residence & $1.18 \%$ & $0.86 \%$ \\
Retail & $1.27 \%$ & $0.80 \%$ \\
Hotel & $2.04 \%$ & $1.12 \%$ \\
Logistics & $1.28 \%$ & $0.65 \%$ \\
Healthcare & $0.73 \%$ & $0.91 \%$ \\
Diversified & $1.18 \%$ & $0.88 \%$ \\
Infrastructure & - & $1.03 \%$ \\
Overall J-REITs market & $1.27 \%$ & $0.87 \%$ \\
\hline
\end{tabular}

Table 11. The average debt cost and dividend yield of industrial and logistics and infrastructure sector Japan and U.S. REITs corporations in FY 2020

\begin{tabular}{llcc}
\hline Country & Sector & Averaged Debt Cost & Averaged Dividend Yield \\
\hline Japan & Industrial and Logistics & $0.65 \%$ & $3.47 \%$ \\
U.S. & & $3.94 \%$ & $3.21 \%$ \\
Japan & Infrastructure with public-utility sub sector & $1.03 \%$ & $6.09 \%$ \\
U.S. & $7.38 \%$ & $5.17 \%$ \\
\hline
\end{tabular}

\section{Conclusion}

In this paper, we investigate the market performance and the return style of pan-infrastructure REITs corporation in U.S. and Japan systematically and draw four aspects of conclusions: 1) The new infrastructure REITs corporations covering data center REITs corporations and communication tower focused REITs corporations exhibit significant defensive characteristics with higher ratio of bond attributes in spite of the increasing uncertainty of macro-environment. 2) The self-storage REITs corporations display remarkable anti-volatility characteristics under the volatile macro environment due to the stable supply and demand relationship. 3) The stock price of industrial \& logistics REITs corporations and three infrastructure REITs corporations belonging to public utility sub-sector fluctuates sharply. It is anticipated that the market performance of such corporations will be inferior to the benchmark and REITs index with the intensification of Sino-U.S. trade conflict and geopolitics risk in future. 4) Thanks to the negative interest rate environment and the following debt financing activity preference, the ratio of bond attributes in the return style of pan-infrastructure REITs corporations in Japan is much higher than the counterparts in U.S., which reveals higher degree of earnings stability.

The growth of 5G communication and digital economy promotes the expansion of new infrastructure facilities market. The above studies regarding the market performance and the return style of data center and communication tower focused infrastructure REITs corporations in U.S. can be perceived as a necessary complement to the traditional recognition that such new infrastructure REITs corporations are associated with the asset intensive and higher degree of debt financing mode and also are beneficial to those emerging countries which aim to achieve the economic transition through the development of new-infrastructure program. Meanwhile, the results that the industrial \& logistics REITs corporations in U.S. shows weak anti-volatility characteristics with higher ratio of stock attributes in their return style also attract the attention of investors from China where the penetration ratio of e-commerce is high and the logistics industry is highly developed. In addition, we also notice that the underlying asset of pan-infrastructure REITs market in U.S. and Japan mainly focuses on the communication tower, energy supplies facilities, data center and industrial \& logistics facilities with higher degree participation of private capital and seldom involves those assets operated by public capital covering rail road, highway, airport and wastewater treatment facilities. How does the return style and market performance of such REITs corporation evolve under different macro environment? Such question needs to be clarified by the extension of corresponding analysis to other REITs market such as Australia, Singapore and China and will be further discussed in the next studies.

Before ending the discussion, we also take a glimpse at the nascent China pan-infrastructure REITs market whose scale will amount to one trillion-dollar level in recent years. The Circular on work related to advancing the pilot program of Real Estate Investment Trusts (REITs) for the infrastructure sector was released by China securities regulatory commission on April 30, 2020, which represents the establishment of publicly-offered 
REITs market in terms of the policy. On Jun 21, 2021, nine public infrastructure REITs whose underlying asset includes the industrial park, highway, logistics facilities, port facilities, waste water treatment facilities and environment protection facilities are listed on the Shanghai and Shenzhen stock exchange signifies the new era of China REITs market. Accordingly, the financial indicator of infrastructure REITs corporations with different underlying asset types vary substantially. The dividend yield of highway and wastewater treatment REITs corporations whose operating program has specific franchise is much higher than that of industrial parks and logistics facilities REITs corporation whose program ownership belongs to the sponsor in principle due to the franchise maturity and higher ratio of asset depreciation and amortization. Are there huge differences or similarities between the return style and market performance of above two types of REITs corporation as U.S. REITs market or Japanese market does, respectively? If the former assumption works, do the bond and stock attributes respectively explain the return style of franchise and ownership-based pan-infrastructure REITs program? The clarification of the above problem not only facilitates the financial institution to evaluate the risk level of corresponding financial product precisely but also improves the risk awareness of investors, and may become a next hot issue for both academia and industry.

\section{References}

ARES. (2009). Monthly report: January 2010. Retrieved from https://j-reit.jp/download/ares_jreitreport_201001_2.pdf

ARES. (2020). Monthly report: January 2021. Retrieved from https://j-reit.jp/download/info/1053.pdf

Bohjalian, T. (2018). Call the Market: Rate Reaction Opens REIT Opportunity. IPE, Real Assets, London.

CBRE. (2018). Global Real Estate Market Outlook. CBRE, Los Angeles.

China securities regulatory commission. (2020). Circular on Work Related to Advancing the Pilot Program of Real Estate Investment Trusts ("REITs") for the Infrastructure Sector. Retrieved from http://www.csrc.gov.cn/pub/newsite/zjhxwfb/xwdd/202004/t20200430_374845.html

Chong, F. (2019). Asia-Pacific: At the Epicentre of Logistics Transformation. IPE Real Assets, London.

Clayton, J., \& MacKinnon, G. (2001). The time-varying nature of the link between REIT, real estate and financial asset returns. Journal of Real Estate Portfolio Management, 7(4), 43-54. https://doi.org/10.1080/10835547.2001.12089632

Clayton, J., \& MacKinnon, G. (2003). The relative importance of stock, bond and real estate factors in explaining REIT returns. The Journal of Real Estate Finance and Economics, 27(1), 39-60. https://doi.org/10.1023/A:1023607412927

Glascock, J. L., Lu, C., \& So, R. W. (2000). Further evidence on the integration of REIT, bond, and stock returns. The Journal of Real Estate Finance and Economics, 20(2), 177-194. https://doi.org/10.1023/A:1007877321475

Honda, Y., \& Inoue, H. (2019). The effectiveness of the negative interest rate policy in Japan: An early assessment. Journal of the Japanese and International Economies, 52, 142-153. https://doi.org/10.1016/j.jjie.2019.01.001

Ito, T. (2021). An Assessment of Abenomics: Evolution and Achievements. Asian Economy Policy Review, 16(2), 190-219. https://doi.org/10.1111/aepr.12353

J-REIT.jp (2020). The Association for Real Estate Securitization. Retrieved from https://j-reit.jp/lp/unyoshisan/

Karolyi, G., \& Sanders, A. B. (1998). The variation of economic risk premiums in real estate returns. The Journal of Real Estate Finance and Economics, 17(3), 245-262. https://doi.org/10.1023/A:1007776907309

Knight Frank. (2018). E-Commerce: All Just a Click Away. Knight Frank, London.

Li, R., \& Chau, K. W. (2016). An econometric analysis on REITs cycles in Hong Kong, Japan, the US and the UK. Econometric Analyses of International Housing Markets, Chapter 11, 163-179. https://doi.org/10.4324/9781315743035

Li, R., Fong, S., \& Chong, K. (2017). Forecasting the REITs and stock indices: Group method of data handling neural network approach. Pacific Rim Property Research Journal, 23(2), 123-160. https://doi.org/10.1080/14445921.2016.1225149

Liang, Y., \& McIntosh, W. (1998). REIT style and performance. Journal of Real Estate Portfolio Management, 4(1), 69-78. https://doi.org/10.1080/10835547.1998.12089552 
Lin, Y. C., Lee, C. L., \& Newell, G. (2020). The added-value role of industrial and logistics REITs in the Pacific Rim region. Journal of Property Investment and Finance, 38(6), 597-616. https://doi.org/10.1108/JPIF-09-2019-0129

Marzuki, M., \& Newell, G. (2019). The emergence of data centers as an innovative alternative property sector. Journal of Property Investment and Finance, 37(2), 140-152. https://doi.org/10.1108/JPIF-08-2018-0064

McIntosh, W., Fitzgerald, M., \& Kirk, J. (2017). Non-Traditional Property Types: Part of a Diversified Real Estate Portfolio. Journal of Portfolio Management, 43(6), 62-72. https://doi.org/10.3905/jpm.2017.43.6.062

NAREIT. (2009). REITWatch: January 2010. National Association of Real Estate Investment Trusts (NAREIT), Washington, DC.

NAREIT. (2016). REIT Sectors. Retrieved from https://www.reit.com/what-reit/reit-sectors

NAREIT. (2020). REITWatch: January 2021. National Association of Real Estate Investment Trusts (NAREIT), Washington, DC.

Nelling, E., \& Gyourko, J. (1998). The predictability of equity REIT returns. Journal of Real Estate Research, 16(3), 251-268. https://doi.org/10.1080/10835547.1998.12090958

Newell, G., \& Peng, H. W. (2008). The role of US infrastructure in investment portfolios. Journal of Real Estate Portfolio Management, 14(1), 21-34. https://doi.org/10.1080/10835547.2008.12089795

Ooi, J. T. L., \& Wong, W. C. (2013). Asian REITs: Growing into Maturity. Real Estate Investment Trusts in Europe, Chapter 7, 77-89. https://doi.org/10.1007/978-3-642-36856-1_7

Oyedele, J. B. (2014). Performance and Significance of UK-Listed Infrastructure in a Mixed-Asset Portfolio. Journal of European Real Estate Research, 7, 199-215. https://doi.org/10.1108/JERER-08-2013-0015

Peterson, J. D., \& Hsieh, C. H. (1997). Do Common Risk Factors in the Returns on Stocks and Bonds Explain Returns on REITs? Real Estate Economics, 25(2), 321-345. https://doi.org/10.1111/1540-6229.00717

Sharpe, W. F. (1992). Asset Allocation. Journal of Portfolio Management, 18(2), 7-19. https://doi.org/10.3905/jpm.1992.409394

$\begin{array}{llll}\text { Tokyo Stock } & \text { Exchange. } & \text { (2020) } & \text { Retrieved }\end{array}$ https://www.jpx.co.jp/english/equities/products/infrastructure/issues/index.html

World Bank. (2018). Connecting to Compete 2018: Trade Logistics in the Global Economy. World Bank, Washington, DC.

Xu, M., Tang, W., \& Zhou, C. (2019). Procurement strategies of E-retailers under different logistics distributions with quality- and service-dependent demand. Electronic Commerce Research and Applications, 35, 100853. https://doi.org/10.1016/j.elerap.2019.100853

Zhu, B. (2018). The time-varying nature of REITs. Real Estate Management and Valuation, 26(1), 26-38. https://doi.org/10.2478/remav-2018-0003

\section{Copyrights}

Copyright for this article is retained by the author(s), with first publication rights granted to the journal.

This is an open-access article distributed under the terms and conditions of the Creative Commons Attribution license (http://creativecommons.org/licenses/by/4.0/). 